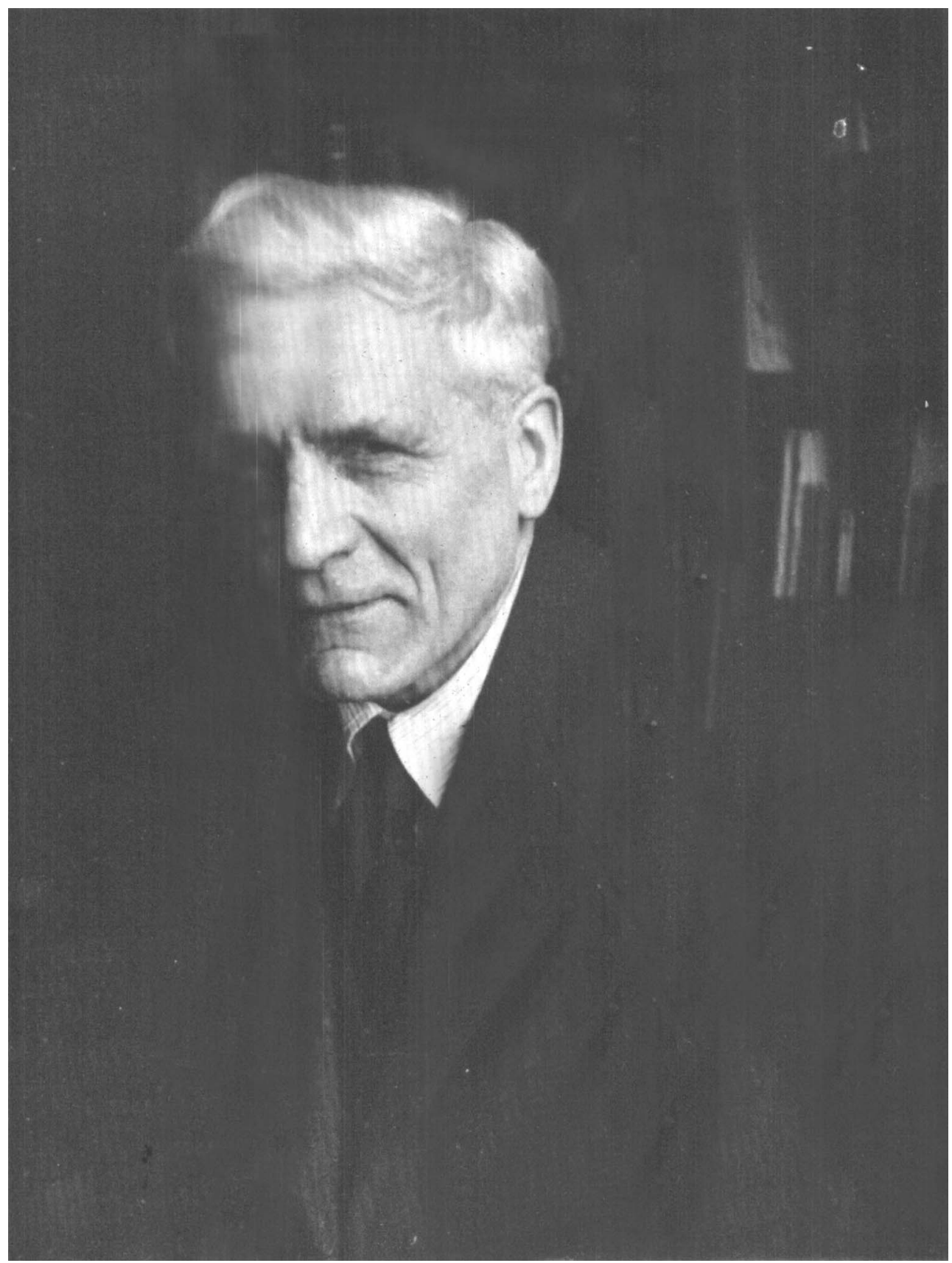

Facing p. 1) 


\section{The 82nd Birthday of James Walter McLeod}

JAMES WALTER MCLEOD, president of the Society for General Microbiology from I 949 to 1952 , was born on 2 January, I 887 , at Dumbarton. He is a striking personality in many ways, and always has inspired deep affection and loyalty of those who came into contact with him.

He graduated M.B., Ch.B. with commendation from the University of Glasgow in 1908 and after holding two house appointments at Glasgow went as a ship's surgeon on a trip to India. After his return in 1909 he was appointed Coats scholar and in I9 Io Carnegie scholar in the Pathology Department of Robert Muir, where he worked under Carl Browning on bacterial haemolysins with special reference to streptococcal haemolysin. In 1912 he was appointed assistant lecturer in pathology at Charing Cross Medical School from where in I9I4 he joined the R.A.M.C. as temporary lieutenant, and later as captain in charge of the 8th mobile laboratory. In this capacity he successfully mixed valour with research for he was mentioned four times in despatches, was awarded the military O.B.E., and published papers on trench fever, trench nephritis, bacillary dysentery and the bacteriology of epidemic influenza. In I9I9 he was appointed Lecturer in Bacteriology in the School of Medicine at Leeds, and from I 920 on was engaged in work on bacterial oxidation-reduction and respiration, particularly of anaerobes. The ten years devoted to these studies culminated in McLeod's contributions to Falk's 'Newer Knowledge of Bacteriology', I 928, and to the Medical Research Council's 'System of Bacteriology', 1930. The practical result dating from this period best known and used all over the world in diagnostic laboratories is the oxidase'reaction for the recognition of the gonococcus in mixed cultures. A natural corollary to the improvement of diagnostic procedures were efforts directed towards the improvement of culture media, notably of the gonococcus and the diphtheria bacillus. In turn, the intensive use of his heated blood tellurite medium for the isolation of Corynebacterium diphtheriae led him to the realisation that there exist three main types of the diphtheria bacillus which he could relate to clinical severity and named accordingly. The wide interest this aroused with both favourable and contradictory reports from all countries, kept him busily engaged on this subject for nearly 20 years which were interspersed with papers on the differential diagnosis of Clostridium oedematiens, tetanus infection in hospital arising from dust in surgical theatres, the value of antiseptics as prophylactic applications to recent experimental wounds, the inhibiting factor of the action of sulphonamides in nutrient media, and the distribution of the whooping cough bacillus in contacts of cases. With all this activity McLeod made a major contribution to the application of scientific methods and knowledge to diagnostic bacteriological procedures from which patients and clinicians have derived great benefit.

This was also the period when J. W. McLeod received the honours of being elected a Corresponding Member of the Soc. de Biologie, a Fellow of the Royal Society, and an honorary Sc.D. of Trinity College, Dublin.

It was inevitable that a man known for his scrupulous fairness had high administrative duties thrust upon him. Thus, from 1948 until his retirement from the Chair of

Vol. 57, No. 3 was issued 7 November 1969 
Bacteriology in 1952, he was Dean of the Medical School at Leeds which left him little time for work at the laboratory bench. After a short period of rest in the Scottish countryside he returned to laboratory work in Edinburgh, where ever since he has been immersed in the bacteriological problems of chronic urinary infection of paraplegics, and of staphylococcal toxins.

J. W. McLeod's spare time has always been taken up by affairs of the Presbyterian Church and the Boy's Brigade, and in his earlier days with athletics, rugby, cricket and hockey. There are many colourful stories about him current, one of the best of which relates that he, a strict teetotaller, narrowly escaped arrest for drunken conduct in public when on a dark crisp winter's night with firm snow underfoot he went down the slope of Mount Preston from his home to the Department on a toboggan singing at the top of his voice and was stopped by a police constable. At the age of 62 when he had missed his connexion at York in the early hours of the morning, he thought nothing of walking to Leeds carrying his suitcase. A chronic hip ailment has, of late, curtailed his vigorous physical activities and has necessitated a major operation which has interrupted his bench work. All his friends, past and present colleagues and associates who have been inspired by J. W. McLeod's enthusiasm, fairness, deep humanity and generosity are glad that a turbulent but complete recovery period has enabled him to continue as an active bacteriologist.

K.E.C. and K.Z. 